\title{
Omalizumab: Anti-IgE Therapy in Severe Allergic Conditions
}

\section{Arzu Didem Yalcin ${ }^{1 *}$ and Atil Bisgin ${ }^{2}$}

${ }^{1}$ Department of Internal Medicine, Antalya Training and Research Hospital, Antalya, Turkey

${ }^{2}$ Department of Medical Genetics, Faculty of Medicine, Cukurova University, Adana, Turkey

\begin{abstract}
Background: The primary use of omalizumab (trade name Xolair) is for patients with severe, persistent and allergic asthma. Our aim was to evaluate the therapeutic efficacy of omalizumab as a treatment modality in patients with different allergic conditions.

Methods: There were eleven patients, whom followed-up with omalizumab therapy in the Immunology - Allergy Clinic, were evaluated by the clinical findings of nasal polyposis, anaphylaxis history, drug allergy, latex allergy, food allergy, autoimmune urticaria, allergic rhino-conjunctivitis, atopic dermatitis, angioedema and venom allergy.

Results: The patients, who had severe persistent asthma for periods ranging from 3 to 8 years, were enrolled in the study. Omalizumab was chosen as a potential new systemic therapy for the patients due to the clinical indication. Clinical symptoms of the all patients with severe persistent asthma were decreased. And in addition, asthma control test and pulmonary function tests were improved up. A severe anaphylactic reaction is prevented in a patient with 48 bee stings.
\end{abstract}

Conclusion: This clinical follow-up of omalizumab treated patients with severe persistent asthma and many different allergic conditions, suggests omalizumab is an effective therapy for asthma and different allergic conditions.

Keywords: Anti-IgE; Allergy; Rhinoconjunctivitis; Asthma; Comorbid conditions

\section{Introduction}

The use of omalizumab has been evaluated in several allergic conditions, including allergic rhinitis, asthma, Churg-Strauss syndrome, atopic eczema, urticaria, angioedema, latex allergy, and concurrently with allergy immunotherapy to try to blunt reactions [110]. While approved by US Food and Drug Administration for asthma, the other indications need to be studied further. In this study, the omalizumab treatment efficacy was studied on severe persistent asthma patients with co-morbid allergic conditions.

The prevalence of respiratory symptoms, asthma, allergic rhinoconjunctivitis and respiratory function impairment among our Mediterranean region of Turkey; Antalya is considered to be higher than rest of the continent because of the climatic conditions [11]. So that omalizumab becomes more important to be used in stabilizing the clinical features of patients having more than one allergic condition.

\section{Materials and Methods}

\section{Patients}

Eleven patients were included in this follow-up study with severe persistentasthma whose mean age was 43 years and patient characteristics were given in table 1 . They were all treated with omalizumab, had allergic rhinoconjunctivitis and all had a family history of atopia. All of the patients were followed-up in the Immunology-Allergy Clinics of Antalya Training and Research Hospital. The clinical findings of nasal polyposis, anaphylaxis history, drug allergy, latex allergy, food allergy, autoimmune urticaria, angioedema and venom allergy was evaluated.

\section{Study design}

The patients' written consent was obtained. All patients received omalizumab therapy for 24 months. Doses of omalizumab were administered every 2 weeks. Symptoms and severity of allergic reactions were recorded before and after being on omalizumab treatment.
Assessments of clinical changes and adverse effects were made at every bimonthly patient visit. These assessments included vital signs, full physical examination, detailed possible allergy incidents, pulmonary function test and asthma control test (QualityMetric Inc.). Serum IgE levels, thyroid antibodies and eosinophil levels were evaluated in all patients.

\section{Skin prick test (SPT)}

SPTs were performed in all patients with standardized latex extract containing high ammonia natural rubber latex, with a battery of 35

\begin{tabular}{|l|l|l|l|l|l|}
\hline $\begin{array}{l}\text { Patient } \\
\text { no. }\end{array}$ & $\begin{array}{l}\text { Age } \\
(\mathbf{y})\end{array}$ & Sex & $\begin{array}{l}\text { Duration of severe } \\
\text { persistent asthma }\end{array}$ & $\begin{array}{l}\text { Total serum } \\
\mathbf{g E E}(\mathbf{I U / m L})\end{array}$ & Thyroid antibodies \\
\hline 1 & 61 & M & 8 & 424 & Negative \\
\hline 2 & 38 & M & 4 & 446 & (+) Antiperoxidase \\
\hline 3 & 47 & F & 6 & 273 & Negative \\
\hline 4 & 41 & F & 6 & 488 & Negative \\
\hline 5 & 18 & F & 4 & 542 & Negative \\
\hline 6 & 56 & F & 4 & 135 & Negative \\
\hline 7 & 49 & M & 3 & 348 & Negative \\
\hline 8 & 33 & F & 5 & 249 & Negative \\
\hline 9 & 18 & M & 4 & 317 & Negative \\
\hline 10 & 61 & M & 3 & 485 & Negative \\
\hline 11 & 51 & F & 4 & 650 & Negative \\
\hline & & & & & \\
\hline
\end{tabular}

Table 1: Patient characteristics.

*Corresponding author: Arzu Didem Yalcin, Department of Internal Medicine, Allergy and Clinical Immunology Unit, Antalya Education and Research Hospital, Antalya, Turkey, E-mail: adidyal@yahoo.com

Received September 04, 2012; Accepted September 17, 2012; Published September 21, 2012

Citation: Yalcin AD, Bisgin A (2012) Omalizumab: Anti-lgE Therapy in Severe Allergic Conditions. J Aller Ther 3:120. doi:10.4172/2155-6121.1000120

Copyright: @ 2012 Yalcin AD, et al. This is an open-access article distributed unde the terms of the Creative Commons Attribution License, which permits unrestricted use, distribution, and reproduction in any medium, provided the original author and source are credited. 


\begin{tabular}{|c|c|c|c|c|c|c|}
\hline P no. & Xolair Dose & Skin test sensitivity & SSTa & Allergic Reaction & $\begin{array}{l}\text { Number } \\
\text { of } \\
\text { Injection }\end{array}$ & $\begin{array}{l}\text { Efficacy of } \\
\text { Omalizumab }\end{array}$ \\
\hline 1 & 375 mg q. 2 wk & Grass, tree, mold, mite & - & Aller rhin conj, AD & 78 & dose 3: AD and NSS improved significantly \\
\hline 2 & $225 \mathrm{mg} \mathrm{q.} 2 \mathrm{wk}$ & Grass, mite, cockroach & + & $\begin{array}{l}\text { Aller rhin conj, NP, MD Aller, } \\
\text { angioedema and UC }\end{array}$ & 72 & $\begin{array}{l}\text { dose 5: improvement in UC and angioedema } \\
\text { attacks and NSS decreased }\end{array}$ \\
\hline 3 & 225 mg q. 2 wk & $\begin{array}{l}\text { Grass, wheat, tree, mold, mite, cock- } \\
\text { roach, dog and cat epithelium }\end{array}$ & - & Aller rhin conj, NP & 63 & dose 3: improvement in NSS \\
\hline 4 & 300 mg q. 2 wk & $\begin{array}{l}\text { Grass, wheat, tree, mold, mite, cock- } \\
\text { roach, honeybee, dog and cat epithelium }\end{array}$ & - & $\begin{array}{l}\text { Aller rhin conj, NP venom aller, } \\
\text { bee-sting anaphylaxis and UC }\end{array}$ & 68 & $\begin{array}{l}\text { dose 1: decrease in NSS, dose } 3 \text { : improve- } \\
\text { ment in UC, dose 12: no anaphylactic reaction } \\
\text { after } 48 \text { honey bee-sting. }\end{array}$ \\
\hline 5 & 300 mg q. 2 wk & $\begin{array}{l}\text { mold, mite, cockroach, tomato, eggplant, } \\
\text { strawberry, dog epithelium }\end{array}$ & - & $\begin{array}{l}\text { Aller rhin conj, NP, food aller and } \\
\text { anaphylaxis (food. induced) }\end{array}$ & 64 & $\begin{array}{l}\text { dose 1: improvement in NSS dose 6: tolerated } \\
\text { food allergy and no food induced UC }\end{array}$ \\
\hline 6 & 300 mg q. 2 wk & $\begin{array}{l}\text { Grass, tree, mite, shrimp, perch, egg } \\
\text { and latex }\end{array}$ & + & $\begin{array}{l}\text { Aller rhin conj, NP, MD aller, food } \\
\text { aller, latex aller, anaphylaxis } \\
\text { (NSAID induced) and AD }\end{array}$ & 72 & $\begin{array}{l}\text { dose 1: NSS decreased } \\
\text { dose 5: AD and food allergy improved signifi- } \\
\text { cantly } \\
\text { dose 10: improvement in UC and angioedema } \\
\text { attacks }\end{array}$ \\
\hline 7 & 300 mg q. 2 wk & wheat, tree, mite. & - & $\begin{array}{l}\text { Aller rhin conj, NP, MD Aller and } \\
\text { AD dermatitis }\end{array}$ & 74 & $\begin{array}{l}\text { dose 3: improvement in NSS } \\
\text { dose 5: improvement in UC }\end{array}$ \\
\hline 8 & 300 mg q. 2 wk & Grass, tree, mite, kiwi and orange & - & $\begin{array}{l}\text { Aller rhin conj, NP, MD aller, } \\
\text { food aller }\end{array}$ & 76 & $\begin{array}{l}\text { dose 3: Improvement in UC attacks, NSS and } \\
\text { F aller. }\end{array}$ \\
\hline 9 & 225 mg q. 2 wk & $\begin{array}{l}\text { Grass, wheat, tree, mold, mite, cock- } \\
\text { roach, honeybee, dog and cat epithelium }\end{array}$ & - & $\begin{array}{l}\text { Aller rhin conj, NP, MD Aller, } \\
\text { venom aller and } A D\end{array}$ & 72 & $\begin{array}{l}\text { dose 2: NSS improved dose 4: no exacerba- } \\
\text { tion in AD }\end{array}$ \\
\hline 10 & $300 \mathrm{mg}$ q. 2 wk & $\begin{array}{l}\text { Grass, mold, } \\
\text { mite, } \\
\text { cockroach }\end{array}$ & - & Aller rhin conj, MD aller, UC & 64 & dose 4: improvement in UC attacks, NSS \\
\hline 11 & $300 \mathrm{mg}$ q. $2 \mathrm{wk}$ & $\begin{array}{l}\text { Grass, tree, } \\
\text { mite, dog epitelia }\end{array}$ & - & Aller rhin conj and $A D$ & 68 & $\begin{array}{l}\text { dose 2: NSS improves } \\
\text { dose 6: no exacerbation in AD }\end{array}$ \\
\hline
\end{tabular}

AD: Atopic Dermatitis; Aller: Allergy; Conj: Conjunctivitis; MD: mMultidrug; NP: Nasal Polyp; NSAID: Non-Steroidal Anti-Inflammatory Drug; NSS: Nasal Symptom Scoring; P: Patient; Rhin: Rhinitis; SSTa: Autologous Serum Skin Test; UC: Urticarial

Table 2: Clinical follow-up criteria and changes with omalizumab.

common and 35 food allergens on the forearm. In additon, venom SPT was performed in 1 patient based on history. SPTs were performed by skilled nursing personnel. Positive tests were counted as wheals of 3 $\mathrm{mm}$ in diameter after 20 minutes. Tests were compared with positive histamine controls and negative saline controls. Commercial extracts used were manufactured by Alyostal ST-IR (Starallergenes S.A.France). No intradermal testing was performed.

\section{Autologous serum skin test}

The test was performed by injecting $0.05 \mathrm{ml}$ of the patient's own serum intradermally into the left flexor forearm, 2 inches below the antecubital crease and a saline control into the right forearm. A reading of the wheal was taken after 30 minutes. A wheal and flare of more than $1.5 \mathrm{~mm}$ diameter than that of the control was considered positive.

\section{Results}

In this clinical follow-up study, 11 patients were on omalizumab treatment and they were all clinically analyzed at our clinic. The patients had severe persistent asthma for periods ranging from 3 to 8 years. All patients maintained significant improvement by history as shown by a decrease in clinical symptoms and increase in asthma control test. The allergic symptoms were improved clinically and summarized in table 2 and the changes in steroid usage were in table 3.

The Asthma Control Test (ACT) and an Asthma Control Questionnaire were completed by all patients at three clinical visits at the beginning of the omalizumab treatment and 48 to 56 weeks apart. Pulmonary function was also measured. All of the patients had an ACT score of $<20$, indicating that asthma was not well controlled on previous treatment, before the omalizumab therapy. As shown in figure 1, after the treatment period of 12 to 24 months of omalizumab, the ACT score increased up to 20-24 which was indicated as "well-controlled" asthma.

\section{Discussion and Conclusions}

Omalizumab was developed for the treatment of severe allergic asthma. It blocks binding of free IgE on basophils and mast cells, thus inhibiting their activation by allergens. Omalizumab treatment significantly reduces the nasal and conjunctival symptom scores of all patients. This demonstrates the effectiveness of omalizumab and these findings agree with recently published data $[12,13]$.

In this follow-up, omalizumab significantly improved asthma control and pulmonary function in patients with severe persistent asthma. Patients no 1,2 and 4 did not show an increase of ACT up to 20. Although, they showed no asthma exacerbation after the treatment, there was a 2.5 fold increase in ACT scoring.

Seven of the patients' had chronic urticaria, while 2 of them with chronic autoimmune urticaria. There is a significant improvement in urticaria attacks beginning from the $3^{\text {rd }}$ dose in all of these patients. However, the patients with autoimmune urticaria had been under treatment for longer period before the symptoms were decreased. Similar results were also reported in previous study about the omalizumab effectivity in the treatment of chronic autoimmune urticaria $[9,14]$.

Patient no 5, 6 and 8 had a history of food allergy. While treating asthma patients with omalizumab, patients subjectively observed a reduction in their concomitant food allergy symptoms as previously reported $[8,15]$.

There is a history of honey-sting allergy in patients no 4 and 9. The patient no 4 had previously reported honeybee induced anaphylaxis. Interestingly in this patient, while having the omalizumab treatment 


\begin{tabular}{|l|l|l|}
\hline Patient no. & $\begin{array}{l}\text { Pre-omalizumab oral steroid } \\
\text { dose }(\mathbf{m g} / \text { day) }\end{array}$ & Post-omalizumab \\
\hline 1 & 6 & 0 \\
\hline 2 & 8 & 0 \\
\hline 3 & 0 & 0 \\
\hline 4 & 12 & 0 \\
\hline 5 & 0 & 0 \\
\hline 6 & 6 & 0 \\
\hline 7 & 0 & 0 \\
\hline 8 & 6 & 0 \\
\hline 9 & 0 & 0 \\
\hline 10 & 10 & 0 \\
\hline 11 & 8 & 0 \\
\hline
\end{tabular}

Table 3: Steroid doses of the patients pre- and post-omalizumab.

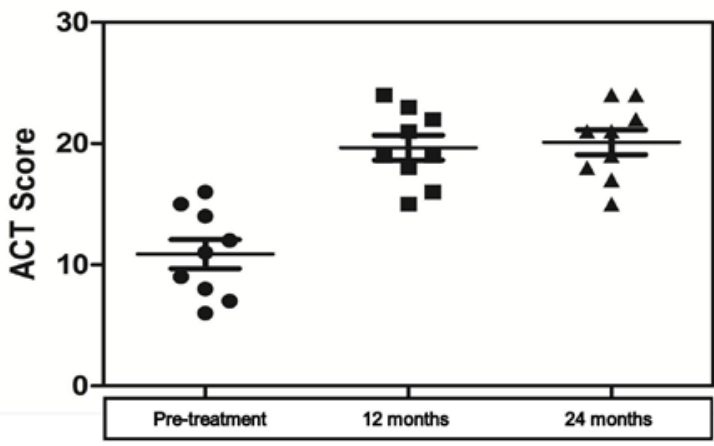

Figure 1: Asthma control test.

on the $12^{\text {th }}$ dose, she had 48 bee-stings and developed only a slight local reaction which resolved spontaneously. The results were in concordance with similar cases that were treated with omalizumab in the literature [16,17]. Allergen immunotherapy has been used in the management of allergic diseases for nearly 100 years [18]. It is the only specific treatment for hymenoptera venom anaphylaxis [19-21]. Various venom immunotherapy schedules have been designed to treat anaphylaxis [22-27]. Though the effect of venom immunotherapy is well documented, there is also an increased risk of side-effects that were in a large range from itchy eyes, sneezing to Jessner lymphocytic infiltrate and severe anaphylaxis in bee-venom-treated patients and in those with rapid dose increase [28-30]. This case suggests that omalizumab may be able to prevent severe anaphylaxis during immunotherapy.

Latex allergy is another important health problem since 1980s. Latex sensitivity was found as $18.1 \%$ in our previous study [31]. The patient no 6 had a history of latex allergy; the improvement in this allergy persists after the $5^{\text {th }}$ dose of omalizumab similar to previously reported in the literature [32].

The most recent studies on severe persistent allergic asthma and the effect of omalizumab treatment, provided novel perspectives on using serum soluble TNF-related apoptosis inducing ligand, nitric oxide, malondialdehyde, hydrogen peroxide and albumin levels, total antioxidant capacity and ceruloplasmin activity as an efficacy marker [33-36].

As a conclusion, our clinical follow-up of omalizumab treated patients with severe persistent asthma suggests that omalizumab is an effective therapy for asthma and as well as for several allergic conditions.

\section{Authors Contributions}

Clinical follow-up: Arzu Didem Yalcin analyzed the data; Atil
Bisgin wrote the paper; Arzu Didem Yalcin and Atil Bisgin drafted the figures. All authors read and approved the final manuscript.

\section{References}

1. Chervinsky P, Casale T, Townley R, Tripathy I, Hedgecock S, et al. (2003) Omalizumab, an anti-lgE antibody, in the treatment of adults and adolescents with perennial allergic rhinitis. Ann Allergy Asthma Immunol 91: 160-167.

2. Casale TB, Condemi J, LaForce C, Nayak A, Rowe M, et al. (2001) Effect of omalizumab on symptoms of seasonal allergic rhinitis: a randomized controlled trial. JAMA 286: 2956-2967.

3. Ayres JG, Higgins B, Chilvers ER, Ayre G, Blogg M, et al. (2004) Efficacy and tolerability of anti-immunoglobulin $\mathrm{E}$ therapy with omalizumab in patients with poorly controlled (moderate-to-severe) allergic asthma. Allergy 59: 701-708.

4. Holgate ST, Chuchalin AG, Hébert J, Lötvall J, Persson GB, et al. (2004) Efficacy and safety of a recombinant anti-immunoglobulin $E$ antibody (omalizumab) in severe allergic asthma. Clin Exp Allergy 34: 632-638.

5. Bousquet J, Cabrera P, Berkman N, Buhl R, Holgate S, et al. (2005) The effect of treatment with omalizumab, an anti-lgE antibody, on asthma exacerbations and emergency medical visits in patients with severe persistent asthma. Allergy 60: 302-308.

6. Chipps B, Buhl R, Beeh KM, Fox H, Thomas K, et al. (2006) Improvement in quality of life with omalizumab in patients with severe allergic asthma. Curr Med Res Opin 22: 2201-2208.

7. Kopp MV, Hamelmann E, Zielen S, Kamin W, Bergmann KC, et al. (2009) Combination of omalizumab and specific immunotherapy is superior to immunotherapy in patients with seasonal allergic rhinoconjunctivitis and comorbid seasonal allergic asthma. Clin Exp Allergy 39: 271-279.

8. Chehade $\mathrm{M}$ (2007) IgE and non-IgE-mediated food allergy: treatment in 2007. Curr Opin Allergy Clin Immunol 7: 264-268.

9. Spector SL, Tan RA (2007) Effect of omalizumab on patients with chronic urticaria. Ann Allergy Asthma Immunol 99: 190-193.

10. Sands MF, Blume JW, Schwartz SA (2007) Successful treatment of 3 patients with recurrent idiopathic angioedema with omalizumab. J Allergy Clin Immunol 120: $979-981$.

11. Yalcin AD, Oncel S, Akcan A (2010) Prevalance of allergic asthma, rhinitis and conjunctivitis in over 16 year old individuals in Antalya. Turkiye Klinikleri J Med Sci 30: 888-894.

12. Adelroth E, Rak S, Haahtela T, Aasand G, Rosenhall L, et al. (2000) Recombinant humanized mAb-E25, an anti-lgE mAb, in birch pollen-induced seasonal allergic rhinitis. J Allergy Clin Immunol 106: 253-259.

13. Hanf G, Noga O, O'Connor A, Kunkel G (2004) Omalizumab inhibits allergen challenge-induced nasal response. Eur Respir J 23: 414-418.

14. Kaplan AP, Joseph K, Maykut RJ, Geba GP, Zeldin RK (2008) Treatment of chronic autoimmune urticaria with omalizumab. J Allergy Clin Immunol 122 569-573.

15. Rafi A, Do LT, Katz R, Sheinkopf LE, Simons CW, et al. (2010) Effects of omalizumab in patients with food allergy. Allergy Asthma Proc 31: 76-83.

16. Galera C, Soohun N, Zankar N, Caimmi S, Gallen C, et al. (2009) Severe anaphylaxis to bee venom immunotherapy: efficacy of pretreatment and concurrent treatment with omalizumab. J Investig Allergol Clin Immunol 19: 225-229.

17. Kontou-Fili K, Filis Cl, Voulgari C, Panayiotidis PG (2010) Omalizumab monotherapy for bee sting and unprovoked "anaphylaxis" in a patient with systemic mastocytosis and undetectable specific IgE. Ann Allergy Asthma Immunol 104: 537-539.

18. (1985) Biological products: allergenic extracts: implementation of efficacy review. Federal register, Food and Drug Administration 21: CRF Parts 600,610 and 680 .

19. Golden DB, Kwiterovich KA, Kagey-Sobotka A, Valentine MD, Lichtenstein LM (1996) Discontinuing venom immunotherapy: outcome after five years. J Allergy Clin Immunol 97: 579-587.

20. Lerch E, Muller UR (1998) Long-term protection after stopping venom immunotherapy: results of re-stings in 200 patients. J Allergy Clin Immunol 101 606-612. 
21. Bousquet J, Muller UR, Dreborg S, Jarisch R, Malling HJ, et al. (1987) Immunotherapy with Hymenoptera venoms. Position paper of the working group on immunotherapy of the european academy of allergy and clinical immunology. Allergy 42: 401-413.

22. Bonifazi F, Jutel M, Biló BM, Birnbaum J, Muller U, et al. (2005) Prevention and treatment of hymenoptera venom allergy: guidelines for clinical practice. Allergy 60: 1459-1470.

23. Shekelle PG, Woolf SH, Eccles M, Grimshaw J (1999) Clinical guidelines: developing guidelines. BMJ 318: 593-596.

24. Moffitt JE, Golden DB, Reisman RE, Lee R, Nicklas R, et al. (2004) Stinging insect hypersensitivity: a practice parameter update. J Allergy Clin Immunol 114: 869-886.

25. (1994) The use of epinephrine in the treatment of anaphylaxis. AAAI Board of Directors. J Allergy Clin Immunol 94: 666-668.

26. Muller U, Mosbech H, Blaauw P, Dreborg S, Malling HJ, et al. (1991) Emergency treatment of allergic reactions to Hymenoptera stings. Clin Exp Allergy 21: 281288.

27. Bilò MB (2011) Anaphylaxis caused by Hymenoptera stings: from epidemiology to treatment. Allergy 66: 35-37.

28. Mosbech H, Müller U (2000) Side-effects of insect venom immunotherapy: results from an EAACI multicenter study. European Academy of Allergology and Clinical Immunology. Allergy 55: 1005-1010.
29. Ruëff F, Przybilla B (2008) Venom immunotherapy. Side effects and efficacy of treatment. Hautarzt 59: 200-205.

30. Yalcin AD, Bisgin A, Akman A, Erdogan G, Çiftcioglu MA, et al. (2012) Jessner lymphocytic infiltrate as a side effect of bee venom immunotherapy. J Investig Allergol Clin Immunol 22: 308-309.

31. Yalcin AD, Çakın Ö, Polat HH, Terzioğlu E (2011) Occupational Disease of Healthcare Workers: Latex Allergy. EMJ 33: 103-110.

32. Leynadier F, Doudou O, Gaouar H, Le Gros V, Bourdeix I, et al. (2004) Effect of omalizumab in health care workers with occupational latex allergy. J Allergy Clin Immunol 113: 360-361.

33. Yalcin AD, Gorczynski RM, Parlak GE, Kargi A, Bisgin A, et al. (2012) Total antioxidant capacity, hydrogen peroxide, malondialdehyde and total nitric oxide concentrations in patients with severe persistent allergic asthma: its relation to omalizumab treatment. Clin Lab 58: 89-96.

34. Yalcin AD, Bisgin A, Kargi A, Gorczynski RM (2012) Serum-soluble TRAIL levels in patients with severe persistent allergic asthma: its relation to Omalizumab treatment. Med Sci Monit 18: PI11-PI15.

35. Yalcin AD, Gumuslu S, Parlak GE, Bisgin A, Yildiz M, et al. (2012) Systemic levels of ceruloplasmin oxidase activity in allergic asthma and allergic rhinitis. Immunopharmacol Immunotoxicol.

36. Yalcin AD, Bisgin A (2012) The relation of strail levels and quality of life in severe persistent allergic asthma patients using omalizumab. Med Sci Monit 18: LE9-LE10. 